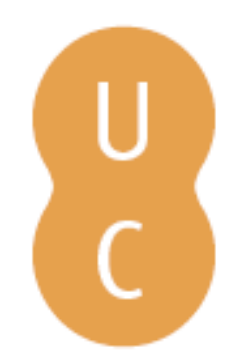

\title{
nommalina
}

\section{Spontaneous ignition of vertically positioned wood samples under time-dependent heat flux}

\author{
Autor(es): $\quad$ Filkov, Alexander I.; Penman, Trent D. \\ Publicado por: Imprensa da Universidade de Coimbra \\ URL \\ persistente: URI:http://hdl.handle.net/10316.2/44682 \\ DOI: $\quad$ DOI:https://doi.org/10.14195/978-989-26-16-506_165 \\ Accessed : $\quad$ 26-Apr-2023 14:30:17
}

A navegação consulta e descarregamento dos títulos inseridos nas Bibliotecas Digitais UC Digitalis, UC Pombalina e UC Impactum, pressupõem a aceitação plena e sem reservas dos Termos e Condições de Uso destas Bibliotecas Digitais, disponíveis em https://digitalis.uc.pt/pt-pt/termos.

Conforme exposto nos referidos Termos e Condições de Uso, o descarregamento de títulos de acesso restrito requer uma licença válida de autorização devendo o utilizador aceder ao(s) documento(s) a partir de um endereço de IP da instituição detentora da supramencionada licença.

Ao utilizador é apenas permitido o descarregamento para uso pessoal, pelo que o emprego do(s) título(s) descarregado(s) para outro fim, designadamente comercial, carece de autorização do respetivo autor ou editor da obra.

Na medida em que todas as obras da UC Digitalis se encontram protegidas pelo Código do Direito de Autor e Direitos Conexos e demais legislação aplicável, toda a cópia, parcial ou total, deste documento, nos casos em que é legalmente admitida, deverá conter ou fazer-se acompanhar por este aviso.

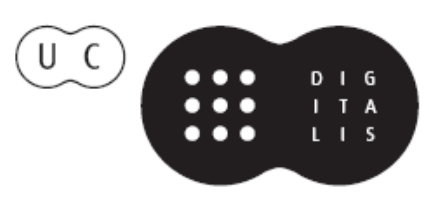




\section{ADVANCES IN}

\section{FOREST FIRE RESEARCH}

\section{8}

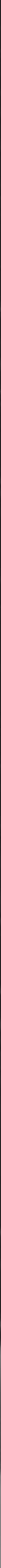


Short contribution - Fire Management

\title{
Spontaneous ignition of vertically positioned wood samples under time-dependent heat flux
}

\author{
Alexander I. Filkov*12, Trent D. Penman ${ }^{1}$

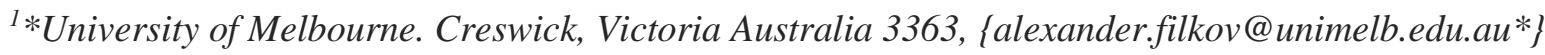 \\ ${ }^{2}$ Bushfire and Natural Hazards Cooperative Research Centre. Melbourne, Victoria Australia 3002, \\ \{office@bnhcrc.com.au\}
}

\begin{abstract}
Dynamic heating regimes are observed during structural and wildland fires. Most experiments to date use static/constant heating regimes, whereas ignition characteristics under time-dependent heat flux has been poorly studied. Existing apparatuses have limitations to study this effect, such as heating conditions and sample size/position. In this study, we conduct experiments on a custom-made apparatus to investigate the spontaneous ignition and convection cooling effect on this ignition of different vertically positioned wood species subjected to both static and dynamic heat fluxes. All experiments were conducted on cypress wood. Temperature, mass and ignition time were recorded during the experiment. Samples were exposed to 30 $\mathrm{kW} / \mathrm{m}^{2}$ static heat flux and increasing heat flux. Preliminary results showed that for static heat flux two out of four samples were ignited at $100 \mathrm{sec}$ and $78 \mathrm{sec}$ with mass consumption $9.5 \%$ and $8 \%$ respectively. Two other samples were smouldered intensively during the heating period without flaming ignition observed. Their consumed mass was 28 and $31 \%$ after 5 minutes. For increasing heat flux, ignition occurred at $743 \pm 7$ sec with mass consumption $20.7 \pm 0.8 \%$ for all four samples. Infrared video showed that flaming ignition for increasing heat flux started after the phase when the wood sample surface cracked into rectangular areas. This led to the heating of a deeper section of the sample, thus generating more pyrolysis gases, which was indirectly confirmed by the two times greater temperature at $3 \mathrm{~mm}$ depth for increasing heat flux. The next step of the proposed research will be to investigate the convective cooling on spontaneous ignition using various types of wood species. Different static and dynamic heating regimes will be used and their influence on the ignition process will be evaluated.
\end{abstract}

Keywords: spontaneous ignition, wood samples, time-dependent heat flux, ignition time

\section{Introduction}

Flame spread is an important parameter in the assessment of fire hazards. Ignition and combustion are dependent on the type of the heat flux, whether it is static or variable. The majority of previous research has used static heat flux, despite dynamic heating regimes being commonly observed during structural and wildland fires.

Dynamic fluxes have been tested (Peterson et al. 2015; Vermesi et al. 2016; Zhai et al. 2017) but these studies have generally been limited. Many only use one regime that is simulated to be either increasing, decreasing or parabolic. Most studies use a cone calorimeter or flame propagation apparatus, which have limitations, such as heating conditions and sample size/position (DiDomizio et al. 2016; Vermesi et al. 2016). Furthermore, the majority of the experiments are conducted for horizontally located samples, which are heated from above in contrast to "classical" fire where the flame propagates horizontally heating the fuel from the side. Chen et al. (2014) demonstrated that ignition time is strongly dependent on sample orientation.

To increase the realism of ignition experiments we experimentally test spontaneous ignition of vertically positioned wood samples subjected to both static and dynamic heat fluxes. 


\section{Methods}

The experiment was conducted using a custom-made Radiative Heat Flux Apparatus (Fig. 1).

The apparatus consists of: 1) radiative panel, 2) linear stage, 3) shutter and PC control system. The radiative panel contains infrared short wave quartz lamps producing radiative heat flux. The radiative panel was installed on a $1.5 \mathrm{~m}$ linear stage that allows the panel to move forward or backward, simulating variable heat flux. An infrared camera (FLIR T1050sc) was used to measure temperatures on the exposed surface with frequency $30 \mathrm{~Hz}$ and resolution $1024 \mathrm{x}$ 768. An DSLR camera (Canon EOS 600D) was used to film the experiment. Square cypress wood samples with a depth of $19 \mathrm{~mm}$ and width of $65 \mathrm{~mm}$ were used. Wood boards were cut into $65 \mathrm{~mm}$ square samples.

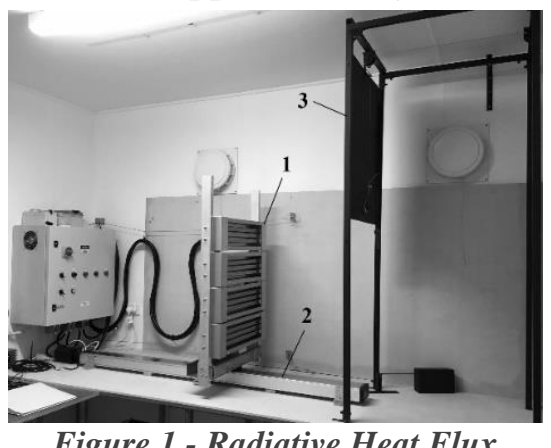

Figure 1 - Radiative Heat Flux Apparatus

One thermocouple was imbedded at a depth of $3 \mathrm{~mm}$ from the exposed surface, two thermocouples - $10 \mathrm{~mm}$ from the exposed surface and one on the back side of the sample. Samples were dried to a constant mass state using an oven at $104{ }^{\circ} \mathrm{C}$ for 48 hours (Kuznetsov and Fil'kov 2011). To avoid the influence of heterogenous wood surface properties (texture, colour etc.) on heat flux absorption, the exposed surface of the sample was coated with lampblack (Kuznetsov and Fil'kov 2011) (fig. 2a). To investigate the influence of convection cooling effect on the ignition time two sample holders were made. One with blocked sides and bottom (fig. $2 \mathrm{~b}$ ) and second without.

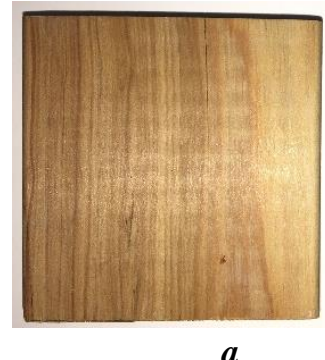

$a$

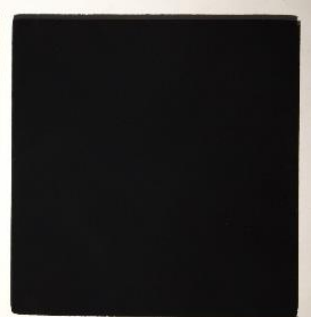

Figure 2 - a) Original (left) and blackened (right) sample; b) sample holder to block convection cooling

The sample holder was constructed of two layers of $7.5 \mathrm{~mm}$ thick cement board. To prevent the heat loss along the edges of the sample internal layer of $25 \mathrm{~mm}$ silica boards was used as an insulation. The entire sample holder was positioned on the scale. Five repetitions were conducted for each condition.

At the first stage, the samples were exposed to $30 \mathrm{~kW} / \mathrm{m}^{2}$ static heat flux during $5 \mathrm{~min}$ and increasing heat flux $12.5 \mathrm{~min}$ duration. The length of time for the increasing regime was chosen to approximate the integral of the heating function. For the dynamic regime, heat flux was increased by moving the radiative panel with a constant speed of $0.4 \mathrm{~mm} / \mathrm{sec}$.

\section{Results and discussion}

Preliminary results showed that for static heat flux $30 \mathrm{~kW} / \mathrm{m}^{2}$, two out of four samples were ignited at $100 \mathrm{sec}$ and $78 \mathrm{sec}$ with mass consumption of $9.5 \%$ and $8 \%$ respectively. Two other samples smouldered intensively during the heating period without flaming ignition. Their consumed mass was $28 \%$ and $31 \%$ after 5 minutes. For increasing heat flux all four samples were ignited at $743 \pm 7 \mathrm{sec}$ with mass consumption of $20.7 \pm 0.8 \%$. Infrared video showed that flaming ignition for increasing heat flux started after the phase when the wood sample surface cracked into rectangular areas. This led to the heating of a deeper section of the sample, thus generating more pyrolysis gases, which was indirectly confirmed by the two times greater temperature at $3 \mathrm{~mm}$ depth for increasing heat flux. For 
static heat flux, the average temperature at the time of ignition was $112{ }^{\circ} \mathrm{C}$ and for the increasing regime it was $219^{\circ} \mathrm{C}$.

The next step of the proposed research will be to investigate the effects of convective cooling and wood type on spontaneous ignition. Different static and dynamic heating regimes will be used and their influence on the ignition will be evaluated. Further investigation is also required to determine why some samples were not ignited in flaming mode under considered static heat flux.

\section{References}

Chen X, Zhou Z, Li P, Zhou D, Wang J (2014) Effects of sample orientation on pyrolysis and piloted ignition of wood. Journal of Fire Sciences 32, 483-497. doi:10.1177/0734904114534612.

DiDomizio MJ, Mulherin P, Weckman EJ (2016) Ignition of wood under time-varying radiant exposures. Fire Safety Journal 82, 131-144. doi:10.1016/j.firesaf.2016.02.002.

Kuznetsov VT, Fil'kov AI (2011) Ignition of various wood species by radiant energy. Combustion, Explosion and Shock Waves 47,. doi:10.1134/S0010508211010096.

Peterson DA, Hyer EJ, Campbell JR, D. FM, Hair JW, Butler CF, Fenn MA (2015) The 2013 Rim Fire: Implications for Predicting Extreme Fire Spread, Pyroconvection, and Smoke Emissions. Bulletin of the American Meteorological Society 96, 229-247. doi:10.1175/BAMS-D-14-00060.1.

Vermesi I, Roenner N, Pironi P, Hadden RM, Rein G (2016) Pyrolysis and ignition of a polymer by transient irradiation. Combustion and Flame 163, 31-41. doi:10.1016/j.combustflame.2015.08.006.

Zhai C, Gong J, Zhou X, Peng F, Yang L (2017) Pyrolysis and spontaneous ignition of wood under time-dependent heat flux. Journal of Analytical and Applied Pyrolysis 125, 100-108. doi:10.1016/j.jaap.2017.04.013. 